\title{
Resistin- and Obesity-associated Metabolic Diseases
}

Author

Affiliation
M. A. Lazar

Division of Endocrinology, Diabetes, and Metabolism, Department of Medicine, and The Institute for Diabetes, Obesity and Metabolism, University of Pennsylvania School of Medicine, Philadelphia, USA

\section{Key words \\ O obesity \\ - insulin resistance \\ - resistin \\ - adipokine}

received $\quad 16.10 .2006$

accepted 01.02.2007

Bibliography

DOI 10.1055/s-2007-985897

Horm Metab Res 2007;

39: 710-716

(c) Georg Thieme Verlag KG

Stuttgart · New York

ISSN 0018-5043

\section{Correspondence}

\section{A. Lazar}

Division of Endocrinology Diabetes and Metabolism

Department of Medicine and

The Institute for Diabetes

Obesity and Metabolism

University of Pennsylvania

School of Medicine

19104-6149 Philadelphia

USA

Tel.: + 1/215/898 0198

Fax: +2/215/8985408

lazar@mail.med.upenn.edu

\section{Abstract \\ $\checkmark$}

The link between obesity and diabetes is strong as well as complex. Fat cells produce many circulating regulators of insulin sensitivity, including pro-inflammatory cytokines. In rodents, resistin is produced by adipose tissue, and is a significant

\section{The problem of obesity-associated metabolic diseases}

Diabetes mellitus (DM) is a chronic disease characterized by hyperglycemia and other metabolic abnormalities. The natural history of DM includes numerous complications including heart disease, stroke, kidney failure, blindness, and neuropathy [1]. Aggressive treatment of hyperglycemia reduces these risks [2]. A minority of patients suffer from type 1 DM, caused by pancreatic $\beta$ cell failure leading to an absolute loss of insulin. Type 2 DM stems from failure of the body to respond normally to insulin-called "insulin resistance"-coupled with the inability to produce enough insulin to overcome this resistant state. This common form of diabetes is often associated with obesity, and the current epidemics of these two conditions are seemingly related [3]. This is glaringly evident in children, who are increasingly plagued by obesity, and in whom the prevalence of type 2 DM (formerly termed "adult onset") is approaching that of type 1 diabetes (formerly termed "juvenile onset") [4]. The epidemic of diabetes has a huge associated cost in terms of healthcare dollars as well as human morbidity and mortality [5]. Recent studies predict that one in three Americans born in the year 2000 will develop diabetes in their lifetime [6]; the vast majority of cases will be obesity-associated type 2 DM.

The mechanism underlying insulin resistance in type $2 \mathrm{DM}$ is not well understood. Except for spo- regulator of glucose metabolism and insulin sensitivity. In humans, resistin is derived made mainly from macrophages. Given the emerging interrelationship between inflammation and metabolic disease, hyperresistinemia may be a biomarker, and/or a mediator, of metabolic and inflammatory diseases in humans as well as in rodents.

\section{Adipose tissue as an endocrine organ $\checkmark$}

Adipose tissue has long been known to secrete free fatty acids (FFA), the product of TG hydrolysis, in response to the body's demand for energy in times of reduced nutrient supply. It is now recognized that increased serum levels of FFA is an important factor contributing to insulin resistance in peripheral tissues [11]. In addition, adipocytes also secrete a variety of polypeptides including leptin, adipsin, adiponectin, resistin, tumor necrosis factor- $\alpha(\mathrm{TNF} \alpha)$, interleukin- 6 (IL6 ), plasminogen activator inhibitor-1 (PAI-1), and monocyte chemoattractant protein-1 (MCP-1) [12]. A subset of these adipose-derived proteins 
is adipocyte-specific, while others are not. In rodents, the adipocyte-specific proteins leptin, adiponectin, and resistin have all been implicated in the modulation of insulin sensitivity. Leptin is an insulin-sensitizing hormone, and deficiency due to leptin gene mutation [13] or reduced adipose mass causes insulin resistance $[14,15]$. In obese states other than that due to leptin gene mutation, however, leptin levels are markedly increased but leptin action is reduced by concomitant leptin resistance [16]. Another adipose-specific hormone, adiponectin, has insulin-sensitizing properties, but its levels are decreased in obesity, thereby contributing to insulin resistance [17]. Resistin, which in rodents is an adipocyte-specific circulating hormone whose increased levels in obesity promote insulin resistance [18], is the subject of this review and will be discussed at great length later in this section.

Intriguingly, quite a few adipose-secreted proteins that are also secreted by other tissues also play a role in innate immunity, a relatively primitive defense mechanism against infection [19]. Proteins such as tumor necrosis factor- $\alpha$ and interleukin- 6 are cytokines that are mainly produced by macrophages. These cytokines directly promote inflammation, and also act on the liver to produce acute phase proteins that contribute to the inflammatory process, and are also produced by adipocytes. A number of these cytokines induce Suppressor of Cytokine Signaling-3 (SOCS-3), an intracellular signaling molecule that impairs the signaling of both leptin and insulin. SOCS-3 levels are elevated in obesity and may thus represent a final common pathway of obesity-associated resistance to the actions of both leptin and insulin [20]. They may also induce cellular insulin resistance via their effects on NF- $\kappa$ B [21] or Jun-kinase [22], in part via serine phosphorylation of the Insulin Receptor Substrates 1 and 2 [23]. Recently, two more molecules produced by fat have been suggested to play a role in glucoregulation. Retinol binding protein 4 (RBP4), although largely produced in liver, is also made by adipocytes, with increased levels in obesity contributing to impaired insulin action [24]. Although the mechanism by which RBP4 regulates glucose homeostasis is unknown, retinoids are known to be potent regulators of immunity [25]. Another adipocyte secreted protein, visfatin, was initially characterized as pre-B-cell colony-enhancing factor, or PBEF [26], yet appears to mimic insulin action [27].

\section{Inflammation and diabetes \\ $\nabla$}

In recent years, an unexpected relationship between inflammation and type 2 DM has emerged. As noted above, several adipocyte-derived factors implicated in insulin resistance are cytokines which are also produced by macrophages. The similarity between macrophages and adipocytes extends beyond cytokine production. Macrophages store abundant amounts of lipid, particularly in states of nutritional excess such as obesity that predispose to atherosclerosic vascular lesions, characterized by lipid-laden macrophages known as foam cells [28]. It has also become evident that macrophage infiltration of adipose tissue is characteristic of obesity $[29,30]$, although the pathophysiological consequences are unknown. The anatomic blurring of the line between adipocytes and macrophages is paralleled by the tissue expression of the polypeptide hormone resistin, whose levels are increased in insulin resistant mice and humans $[31,32]$. The close relationship between inflammation and diabetes is supported by the observation that stimulation of the innate immune response, for example by bacterial endotoxin during sepsis [33], results in insulin resistance that contributes to the high mortality of critical illness [34]. The interaction between inflammation and insulin signaling is also suggested by the ability of aspirin to improve insulin resistance, in part by preventing the antagonistic effects of fatty acids and cytokines [35]. Perhaps the response to infection is more effective when glucose is shunted from muscle to the inflammatory cells involved in the immune response and tissue repair [36].

\section{Peroxisome Proliferator Activated Receptor $\gamma$ (PPAR $\gamma$ ) and insulin sensitivity} $\nabla$

PPAR $\gamma$, a member of the nuclear hormone receptor superfamily of ligand-regulated transcription factors, is the molecular target of the thiazolidinedione (TZD) class of antidiabetic drugs that improve insulin sensitivity throughout the body [37]. PPAR $\gamma$ expression in adipose tissue is 10-100-fold greater than in muscle and liver $[38,39]$ and mice lacking adipose tissue fail to respond to TZD treatment $[40,41]$ whereas mice lacking PPAR $\gamma$ in skeletal muscle retain normal responsivity to TZDs [42]. These observations strongly suggest that the antidiabetic actions of TZDs are mediated by changes in adipose-secreted products; our laboratory and others have hypothesized that the adipocyte-secreted factors altered by TZD treatment are likely to play a role in the pathophysiology of obesity-associated insulin resistance and diabetes [43]. Indeed, TZDs lower plasma FFA levels, by concerted effects on adipocyte FFA uptake [44], recycling $[45,46]$, and release [47] that, together, lead to increased lipid partitioning from the rest of the body to adipose tissue. TZDs also affect the gene expression of adipocyte-secreted products, inducing adiponectin $[48,49]$, while decreasing leptin [50,51], RBP4 [24], and resistin $[18,52]$. Of note, PPAR $\gamma$ is also expressed at high levels in macrophages, where its role in lipid storage is analogous to its function in adipose tissue $[53,54]$. PPAR $\gamma$ ligands also have anti-inflammatory actions in macrophages, largely via downregulation of gene expression $[55,56]$.

\section{Resistin: A mediator of insulin resistance in the rodent}

$\nabla$

This review is focused on resistin, which we discovered in 2001 as a TZD downregulated gene in mouse adipocytes [18]. Resistin is expressed exclusively in adipocytes in mice [18], but is found predominantly in macrophages in humans [57]. TZDs inhibit resistin gene expression in human macrophages $[57,58]$ and lower serum resistin levels in humans as well as rodents [5961]. In rodents, evidence is accumulating that resistin impairs insulin sensitivity. Circulating levels of resistin are increased in obesity [31], and an increase in serum resistin levels has been shown to induce insulin resistance in several rat and mouse models, including acute administration [18,62], adenoviralmediated hepatic gene delivery [63], and transgenic expression $[64,65]$. All of these studies suggest that hyperresistinemia causes insulin resistance and predisposes to type $2 \mathrm{DM}$. Consistent with the conclusions from gain of function studies, loss of resistin signaling improves insulin sensitivity and glucose homeostasis in several rodent models including antibody neutralization [18], germline gene mutation [66], reduced gene expression 
using antisense oligonucleotides [67], or transgenic expression of a dominant negative form [68].

The structure of resistin is unique, with the exception of a small family of related proteins called Resistin-Like Molecules (RELMs) or Found in Inflammatory Zone (FIZZ) factors [69,70]. All of these proteins are cysteine-rich, with the cysteines in a signature pattern not found in any other known proteins. Mouse preresistin is 114 amino acids, and the secreted form consists of 94 amino acids, of which 11 are cysteine. Resistin migrates as a dimer on nonreducing SDS-PAGE gels, and this is entirely due to a single intermolecular disulfide bond involving the most N-terminal cysteine (C26 of the pre-resistin, C6 in the secreted form) of the molecule [71]. The remaining 10 of cysteines form intramolecular disulfide bonds, giving the C-terminus a compact shape [72]. The dimeric form of resistin is active in vivo and in cultured cells [72], and retains biological activity in vitro and in vivo with a Flag epitope at the C-terminus of each resistin molecule $[18,73]$.

\section{Resistin and vascular disease}

$\nabla$

Several studies have demonstrated effects of resistin on vascular cell function that might be expected to contribute to vascular disease. Resistin increases the expression of the adhesion molecules VCAM-1 and ICAM-1, upregulates the monocyte chemoattractant chemokine-1, and promotes endothelial cell activation via ET-1 release [74]. In human saphenous vein endothelial cells, resistin promotes proliferation in part by inducing endothelin-1 [75]. In two additional studies, resistin also increased the proliferation of human aortic smooth muscle cells, as well as the expression of adhesion molecules including VCAM-1 and ICAM1 [76,77]. Resistin also stimulates the macrophage secretion of pro-inflammatory cytokines [78]. Potentially connected to these findings, studies in Japanese and American patients have observed a correlation between increased serum resistin levels and atherosclerosis $[79,80]$. Excitingly, a study published recently demonstrated increased resistin expression in mouse atherosclerotic lesions, correlating with increased circulating resistin levels in humans with premature coronary artery disease [81].

\section{Resistin signaling \\ $\nabla$}

The signaling mechanism(s) by which resistin impairs insulin action are just beginning to be unraveled. The receptor for resistin is unknown. We have preliminary evidence for resistin binding to mouse hepatocytes and adipocytes, and are attempting to clone the receptor in studies being performed in parallel to those in this proposal, funded by a Freedom to Discover grant from BMS Research Foundation to the PI that is intended to support high risk projects. We are not requesting funding for these studies in this proposal, both because of their risky nature as well as the high cost of the experiments, which would not be feasible to include in the modest budget of the present project. However, the present studies, particularly those in Aim 2, will inform the receptor studies and, likewise, the present studies will benefit from any new information on the receptor (from this lab or elsewhere). Downstream of its putative receptor, resistin appears to inhibit the AMP-activated kinase (AMPK) in liver and, in some reports, muscle $[63,66,67]$. AMPK serves as a fuel gauge and is known to inhibit hepatic gluconeogenesis and stimulate muscle glucose uptake [82]. In addition, we have recently observed that resistin activates SOCS-3 in mouse adipose tissue [73]. As noted earlier, SOCS-3 is known to suppress insulin signaling in several tissues [83-86], including adipose tissue [20]. Thus at least two intracellular signaling pathways are likely to be downstream of the resistin and insulin receptors, and contribute to the antagonism of insulin action by resistin.

\section{Critical questions regarding resistin physiology and pathophysiology in the mouse $\nabla$}

Several important questions about these effects of resistin in the rodent remain unanswered. First, what is the relationship between resistin and leptin? The gene expression and serum levels of leptin and resistin are remarkably similar; both have diurnal variation and are higher in fed than in fasted animals. Second, what insulin-responsive tissues are most affected by resistin? This appears to be highly dependent on the model being studied. In the hyperresistinemic rat, insulin action in muscle was affected more than liver $[63,64]$, whereas in the mouse the effects on liver have been pronounced without major changes in insulin signaling observed in muscle [66,67]. The first and second specific aims of this proposal address these important issues. Furthermore, questions have been raised about the physiological role of disulfide linked/dimeric versus reduced/monomeric forms of resistin. A resistin missense mutant without the $\mathrm{N}$-terminal cysteine residue and therefore lacking the intermolecular disulfide bridge was shown to have increased stimulatory activity on hepatic glucose production in euglycemic hyperinsulinemic clamp studies in vivo [72]. However, a similar monomeric mutant had little or no activity in cardiac myocytes where wild type dimeric resistin impaired insulin stimulated glucose uptake [87]. These data suggest that the monomeric form may have different activities in different cell types, perhaps under different conditions. Similar tissue specific effects have been demonstrated for different molecular forms of adiponectin [88].

\section{Human resistin}

$\nabla$

While many important questions remain, it is clear that adipocyte-derived resistin plays major roles in normal glucose homeostasis as well as in the pathophysiology of insulin resistance in rodents. As with all rodent models, a major question is whether these conclusions translate to the human situation. Two aspects of resistin biology are particularly relevant to this issue. First, although the human and mouse protein sequences are highly related, their identity of $\sim 60 \%$ is less than usual for hormones with conserved functions across species, although there are precedents such as parathyroid hormone (PTH) which is 70\% (59/84 amino acids) identical between mouse and human (BLAST comparison, data not shown); indeed, both mouse and human PTH and PTH-related polypeptide bind to the same receptor despite less than $30 \%$ overall amino acid identity (BLAST comparison, data not shown). In the case of resistin, the human and mouse genes are syntenic (on human chromosome 19 and mouse chromosome 8), and exhaustive attempts to find another human resistin gene have been unsuccessful $[18,89]$. Hence, the gene identified as human resistin is highly likely to be the mouse ortholog. The human and mouse promoter 
sequences are also quite divergent [89-91], and in this context it is not surprising that the adipose-specific gene expression of rodent is not recapitulated in humans. Indeed, although resistin mRNA is detectable in human adipose tissue [92], it is expressed at much higher levels in mononuclear cells including macrophages $[57,93]$. Inflammatory stimuli also induce resistin in human monouclear cells as well as in human serum $[58,94]$.

Given the tremendous potential value of translating the mouse data to the human, it is critical to determine whether levels of resistin are increased in human obesity, insulin resistance, and/ or type 2 diabetes, and whether hyperresistinemia is a contributing factor to these pathophysiological states in humans. Several groups have failed to identify changes in resistin levels in obesity, insulin resistance, or type 2 DM [95-99]. Yet quite a few others, studying diverse populations using different assays, have found significant relationships with one or more of these conditions $[32,100-115]$. In interpreting the opposing conclusions of some studies, it must be recognized that the resistin assays being used are often quite different from one another, and all are new and not well-validated. Moreover, they are being applied to very diverse populations. In addition, there may be multiple molecular weight forms of circulating resistin. The crystal structure of resistin suggests that it too may form higher molecular weight oligomers that represent noncovalent trimers of the disulfide linked dimeric unit [72]. Indeed, a recent report has documented very high molecular weight forms of resistin in the circulation of children and adults [95]. This is intriguing in light of recent observations that high molecular weight oligomeric forms of adiponectins may be more predictive of insulin sensitivity than the total adipoectin level [116]. This may be another reason why different studies have come to different conclusions about the relationship between hyperresistinemia and disease in humans.

Resistin levels have also been reported to correlate with atherosclerotic cardiovascular disease $[79,80,117]$ as well as C-reactive peptide and other inflammatory factors $[79,100,118,119]$. The correlation with inflammation is particularly noteworthy given the observation that resistin is produced by macrophages in response to inflammatory signals, and the increasing recognition that obesity, type 2 diabetes, and atherosclerosis are inflammatory diseases. Indeed, proinflammatory cytokines whose levels are increased in obesity and diabetes, such as TNF $\alpha$ and IL-6, dramatically induce resistin in human macrophages $[58,120]$. Moreover, resistin itself markedly stimulates the expression of proinflammatory cytokines in human mononuclear cells [91]. Thus, the communication between adipocytes and macrophages may lead to hyperresistinemia even if human resistin is mainly expressed in macrophages.

There is also genetic evidence that resistin may play a role in obesity, insulin resistance, and/or type $2 \mathrm{DM}$ in humans. A single nucleotide polymorphism at the promoter region $(-420 \mathrm{C} \rightarrow \mathrm{G})$ has been significantly linked to obesity and/or insulin resistance in several populations in Europe, Japan, and the United States $[32,103,105,121-126]$. Intriguingly, this polymorphism introduces an Sp1 site that increases resistin gene promoter activity in transient transfection transcription assays $[32,124,127]$. This correlates with increased circulating resistin levels in other studies $[32,105,128]$, including one that showed a gene dosage effect of the single nucleotide substitution on serum resistin levels [32]. Meta-analysis of several studies involving over 4000 patients confirmed the relationship between this resistin gene polymorphism and type 2 DM [32]. The large number of cross- sectional and genetic studies in support of a role of resistin in human disease is promising.

\section{Conclusion \\ $\checkmark$}

The link between obesity and diabetes is strong, and inexorably increasing as a public health menace. Over the past 10 years, there have been major changes in how scientists view this problem. The fat cell is an endocrine organ, producing many potential mediators of insulin resistance including pro-inflammatory cytokines. At the same time, obesity, type 2 diabetes, and cardiovascular disease are increasingly recognized as having inflammatory components. Resistin is a potential mediator of the obesity-diabetes link. In rodents, resistin expression is limited to adipose tissue, and resistin deleteriously affects glucose metabolism and insulin sensitivity in at least some models. Much still needs to be learned about the scope of resistin functions, and its mechanism of action. In humans, resistin appears to be an inflammatory molecule made mainly in macrophages, but given the interrelationship between inflammation and metabolic disease, and between adipocytes and macrophages, a conserved role of hyperresistinemia in the modulation of glucose metabolism and in the pathogenesis of insulin resistance is quite plausible. Resistin may thus be a biomarker and, potentially, a mediator of metabolic and inflammatory disease that could be targeted by novel therapies aimed at stemming the tide of the epidemic of insulin resistance and its metabolic and cardiovascular complications.

\section{Acknowledgments}

I thank my laboratory group for stimulating discussions, and the National Institute for Diabetes, Digestive, and Kidney Diseases for supporting research on resistin in my laboratory (DK49780, DK49210).

\section{References}

1 Nathan DM. Long-term complications of diabetes mellitus. New Eng J Med 1993; 328: 1676-1685

2 Crofford OB. Diabetes control and complications. Ann Rev Med 1995; 46: $267-279$

3 Mokdad AH, Ford ES, Bowman BA, Dietz WH, Vinicor F, Bales VS, Marks $J S$. Prevalence of obesity, diabetes, and obesity-related health risk factors, 2001. JAMA 2003; 289: 76-79

4 Dietz WH. Overweight in childhood and adolescence. N Engl J Med 2004; 350: 855-857

5 Hogan P, Dall T, Nikolov P. Economic costs of diabetes in the US in 2002. Diabetes Care 2003; 26: 917-932

6 Narayan KM, Boyle JP, Thompson TJ, Sorensen SW, Williamson DF Lifetime risk for diabetes mellitus in the United States. JAMA 2003; 290: $1884-1890$

7 Kahn CR, Vicent D, Doria A. Genetics of non-insulin-dependent (type II) diabetes mellitus. Ann Rev Med 1996; 47: 509-531

8 Kamin D, Hadigan C, Lehrke M, Mazza S, Lazar MA, Grinspoon S. Resistin levels in human immunodeficiency virus-infected patients with lipoatrophy decrease in response to rosiglitazone. J Clin Endocrinol Metab 2005; 90: 3423-3426

9 Ahima RS, Flier JS. Adipose tissue as an endocrine organ. Trends Endocrinol Metab 2000; 11: 327-332

10 Steppan CM, Lazar MA. Resistin and obesity-associated insulin resistance. Trends Endocrinol Metab 2002; 13: 18-23

11 Boden $\mathrm{G}$. Role of fatty acids in the pathogenesis of insulin resistance and NIDDM. Diabetes 1997; 46: 1-10

12 Kershaw EE, Flier JS. Adipose tissue as an endocrine organ. J Clin Endocrinol Metab 2004; 89: 2548-2556 
13 Zhang $Y$, Proenca $R$, Maffei M, Barone M, Leopold L, Friedman JM. Positional cloning of the mouse obese gene and its human homologue. Nature 1994; 372: 425-432

14 Shimomura I, Hammer RE, Ikemoto S, Brown MS, Goldstein JL. Leptin reverses insulin resistance and diabetes mellitus in mice with congenital lipodystrophy. Nature 1999; 401: 73-76

15 Oral EA, Simha V, Ruiz E, Andewelt A, Premkumar A, Snell P, Wagner AJ, Paoli AM De, Reitman ML, Taylor SI, Gorden P, Garg A. Leptinreplacement therapy for lipodystrophy. N Engl J Med 2002; 346 : 570-578

16 Ahima RS, Flier JS. Leptin. Annu Rev Physiol 2000; 62: 413-437

17 Trujillo ME, Scherer PE. Adiponectin-journey from an adipocyte secretory protein to biomarker of the metabolic syndrome. J Intern Med 2005; 257: 167-175

18 Steppan CM, Bailey ST, Bhat S, Brown EJ, Banerjee RR, Wright CM, Patel HR, Ahima RS, Lazar MA. The hormone resistin links obesity to diabetes. Nature 2001; 409: 307-312

19 Gabay C, Kushner I. Acute-phase proteins and other systemic responses to inflammation. N Engl J Med 1999; 340: 448-454

20 Shi H, Tzameli I, Bjorbaek C, Flier JS. Suppressor of cytokine signaling 3 is a physiological regulator of adipocyte insulin signaling. J Biol Chem 2004; 279: 34733-34740

21 Shoelson SE, Lee J, Yuan M. Inflammation and the IKK beta/I kappa B/NF-kappa B axis in obesity- and diet-induced insulin resistance. Int J Obes Relat Metab Disord 2003; 27 (Suppl 3): S49-S52

22 Wellen KE, Hotamisligil GS. Inflammation, stress, and diabetes. J Clin Invest 2005; 115: 1111-1119

23 White MF. Insulin signaling in health and disease. Science 2003; 302: 1710-1711

24 Yang Q, Graham TE, Mody N, Preitner F, Peroni OD, Zabolotny JM, Kotani K, Quadro L, Kahn BB. Serum retinol binding protein 4 contributes to insulin resistance in obesity and type 2 diabetes. Nature 2005; 436: 356-362

25 Kuenzli S, Tran C, Saurat JH. Retinoid receptors in inflammatory responses: a potential target for pharmacology. Curr Drug Targets Inflamm Allergy 2004; 3: 355-360

26 Samal B, Sun Y, Stearns G, Xie C, Suggs S, MacNiece I. Cloning and characterization of the cDNA encoding a novel human pre-B-cell colony-enhancing factor. Mol Cell Biol 1994; 14: 1431-1437

27 Fukuhara A, Matsuda M, Nishizawa M, Segawa K, Tanaka M, Kishimoto K, Matsuki Y, Murakami M, Ichisaka T, Murakami $H$ Watanabe E, Takagi T, Akiyoshi M, Ohtsubo T, Kihara S, Yamashita S, Makishima M, Funahashi T, Yamanaka S, Hiramatsu R, Matsuzawa Y, Shimomura I. Visfatin: a protein secreted by visceral fat that mimics the effects of insulin. Science 2005; 307: 426-430

28 Lehrke M, Lazar MA. Inflamed about obesity. Nat Med 2004; 10: 126-127

29 Xu H, Barnes GT, Yang Q, Tan G, Yang D, Chou CJ, Sole J, Nichols A, Ross JS, Tartaglia LA, Chen $H$. Chronic inflammation in fat plays a crucial role in the development of obesity-related insulin resistance. J Clin Invest 2003; 112: 1821-1830

30 Weisberg SP, MacCann D, Desai $M$, Rosenbaum $M$, Leibel $R L$, Ferrante Jr AW. Obesity is associated with macrophage accumulation in adipose tissue. J Clin Invest 2003; 112: 1796-1808

31 Rajala MW, Qi Y, Patel HR, Takahashi N, Banerjee R, Pajvani UB, Sinha MK, Gingerich RL, Scherer PE, Ahima RS. Regulation of resistin expression and circulating levels in obesity, diabetes, and fasting. Diabetes 2004; 53: 1671-1679

32 Osawa H, Yamada K, Onuma H, Murakami A, Ochi M, Kawata H, Nishimiya T, Niiya T, Shimizu I, Nishida W, Hashiramoto M, Kanatsuka A, Fujii $Y$, Ohashi J, Makino $H$. The G/G genotype of a resistin singlenucleotide polymorphism at -420 increases type 2 diabetes mellitus susceptibility by inducing promoter activity through specific binding of Sp1/3. Am J Hum Genet 2004; 75: 678-686

33 Agwunobi AO, Reid C, Maycock P, Little RA, Carlson GL. Insulin resistance and substrate utilization in human endotoxemia. J Clin Endocrinol Metab 2000; 85: 3770-3778

34 Berghe $G$ Van den. How does blood glucose control with insulin save lives in intensive care? J Clin Invest 2004; 114: 1187-1195

35 Yuan $M$, Konstantopoulos $N$, Lee J, Hansen $L$, Li ZW, Karin M, Shoelson SE. Reversal of obesity- and diet-induced insulin resistance with salicylates or targeted disruption of Ikkbeta. Science 2001; 293: 1673-1677

36 Fernandez-Real JM, Ricart $W$. Insulin resistance and inflammation in an evolutionary perspective: the contribution of cytokine genotype/ phenotype to thriftiness. Diabetologia 1999; 42: 1367-1374

37 Lehmann JM, Moore LB, Smith-Oliver TA, Wilkison WO, Willson TM Kliewer SA. An antidiabetic thiazolidinedione is a high affinity ligand for the nuclear peroxisome proliferator-activated receptor $\gamma$ (PPAR $\gamma$ ). J Biol Chem 1995; 270: 12953-12956

38 Chawla A, Schwarz EJ, Dimaculangan DD, Lazar MA. Peroxisome proliferator-activated receptor $\gamma(\operatorname{PPAR} \gamma)$ : Adipose predominant expression and induction early in adipocyte differentiation. Endocrinology 1994; 135: 798-800

39 Tontonoz P, Hu E, Graves RA, Budavari AI, Spiegelman BM. MPPAR $\gamma 2$ : tissue-specific regulator of an adipocyte enhancer. Genes Dev 1994; 8: $1224-1234$

40 Chao L, Marcus-Samuels B, Mason MM, Moitra J, Vinson C, Arioglu E, Gavrilova O, Reitman ML. Adipose tissue is required for the antidiabetic, but not for the hypolipidemic, effect of thiazolidinediones. J Clin Invest 2000; 106: 1221-1228

41 Pajvani UB, Trujillo ME, Combs TP, Iyengar P, Jelicks L, Roth KA Kitsis RN, Scherer PE. Fat apoptosis through targeted activation of caspase 8: a new mouse model of inducible and reversible lipoatrophy. Nat Med 2005; 11: 797-803

42 Norris AW, Chen L, Fisher SJ, Szanto I, Ristow M, Jozsi AC, Hirshman MF, Rosen ED, Goodyear LJ, Gonzalez FJ, Spiegelman BM, Kahn CR. Muscle-specific PPARgamma-deficient mice develop increased adiposity and insulin resistance but respond to thiazolidinediones. J Clin Invest 2003; 112: 608-618

43 Rangwala SM, Lazar MA. Peroxisome proliferator-activated receptor gamma in diabetes and metabolism. Trends Pharmacol Sci 2004; 25: 331-336

44 Martin G, Schoonjans K, Staels B, Auwerx J. PPAR $\gamma$ activators improve glucose homeostasis by stimulating fatty acid uptake in the adipocytes. Atherosclerosis 1998; 137 (Suppl): S75-S80

45 Guan HP, Li Y, Jensen MV, Newgard CB, Steppan CM, Lazar MA. A futile metabolic cycle activated in adipocytes by antidiabetic agents. Nat Med 2002; 8: 1122-1128

46 Tordjman J, Chauvet G, Quette J, Beale EG, Forest C, Antoine B. Thiazolidinediones block Fatty Acid release by inducing glyceroneogenesis in fat cells. J Biol Chem 2003; 278: 18785-18790

47 Souza SC, Yamamoto MT, Franciosa MD, Lien P, Greenberg AS. BRL 49653 blocks the lipolytic actions of tumor necrosis factor-alpha: a potential new insulin-sensitizing mechanism for thiazolidinediones. Diabetes 1998; 47: 691-695

48 Maeda N, Takahashi M, Funahashi T, Kihara S, Nishizawa H, Kishida $K$ Nagaretani H, Matsuda M, Komuro R, Ouchi N, Kuriyama H, Hotta K, Nakamura T, Shimomura I, Matsuzawa Y. PPARgamma ligands increase expression and plasma concentrations of adiponectin, an adipose-derived protein. Diabetes 2001; 50: 2094-2099

49 Yamauchi T, Kamon J, Waki H, Murakami K, Motojima K, Komeda K, Ide T, Kubota N, Terauchi $Y$, Tobe K, Miki H, Tsuchida A, Akanuma $Y$, Nagai R, Kimura S, Kadowaki T. The mechanisms by which both heterozygous peroxisome proliferator-activated receptor gamma (PPARgamma) deficiency and PPARgamma agonist improve insulin resistance. J Biol Chem 2001; 276: 41245-41254

50 Kallen $C B$, Lazar MA. Antidiabetic thiazolidinediones inhibit leptin (ob) gene expression in 3T3-L1 adipocytes. Proc Natl Acad Sci USA 1996; 93: 5793-5796

51 DeVos P, Lefebvre AM, Miller SG, Guerre-Millo M, Wong K, Saladin R, Hamann LG, Staels B, Briggs MR, Auwerx J. Thiazolidinediones repress ob gene expression in rodents via activation of peroxisome proliferator-activated receptor gamma. J Clin Invest 1996; 98: 1004-1009

52 Haugen $F$, Jorgensen A, Drevon CA, Trayhurn P. Inhibition by insulin of resistin gene expression in 3T3-L1 adipocytes. FEBS Lett 2001; 507: 105-108

53 Nagy L, Tontonoz P, Alvarez JG, Chen H, Evans RM. Oxidized LDL regulates macrophage gene expression through activation of PPAR $\gamma$. Cell 1998; 93: 229-240

54 Tontonoz P, Nagy L, Alvarez JG, Thomazy VA, Evans RM. PPAR $\gamma$ promotes monocyte/macrophage differentiation and uptake of oxidized LDL. Cell 1998; 93: 241-252

55 Ricote M, Li AC, Willson TM, Kelly CJ, Glass CK. The peroxisome proliferator-activated receptor-g is a negative regulator of macrophage activation. Nature 1998; 391: 79-82

56 Li M, Pascual G, Glass CK. Peroxisome proliferator-activated receptor gamma-dependent repression of the nitric oxide synthase gene. Mol. Cell. Biol. 2000; 20: 4699-4707

57 Patel L, Buckels AC, Kinghorn IJ, Murdock PR, Holbrook JD, Plumpton $\mathrm{C}$, Macphee $\mathrm{CH}$, Smith SA. Resistin is expressed in human macrophages and directly regulated by PPAR gamma activators. Biochem Biophys Res Commun 2003; 300: 472-476

58 Lehrke M, Reilly MP, Millington SC, Iqbal N, Rader DJ, Lazar MA. An inflammatory cascade leading to hyperresistinemia in humans. PLoS Med 2004; 1: e45 
59 Jung HS, Youn BS, Cho YM, Yu KY, Park HJ, Shin CS, Kim SY, Lee HK, Park KS. The effects of rosiglitazone and metformin on the plasma concentrations of resistin in patients with type 2 diabetes mellitus. Metabolism 2005; 54: 314-320

60 Kamin D, Hadigan C, Lehrke M, Mazza S, Lazar MA, Grinspoon S. Resistin levels in HIV-infected patients with lipoatrophy decrease in response to rosiglitazone. J Clin Endocrinol Metab 2005; 90: 3423-3426

61 Miyazaki Y, Glass L, Triplitt C, Matsuda M, Cusi K, Mahankali A, Mahankali S, Mandarino LJ, DeFronzo RA. Effect of rosiglitazone on glucose and non-esterified fatty acid metabolism in Type II diabetic patients. Diabetologia 2001; 44: 2210-2219

62 Rajala MW, Obici S, Scherer PE, Rossetti L. Adipose-derived resistin and gut-derived resistin-like molecule-beta selectively impair insulin action on glucose production. J Clin Invest 2003; 111: 225-230

63 Satoh H, Nguyen MT, Miles PD, Imamura T, Usui I, Olefsky JM. Adenovirus-mediated chronic "hyper-resistinemia" leads to in vivo insulin resistance in normal rats. J Clin Invest 2004; 114: 224-231

64 Pravenec $M$, Kazdova L, Landa V, Zidek V, Mlejnek P, Jansa P, Wang J, Qi N, Kurtz TW. Transgenic and recombinant resistin impair skeletal muscle glucose metabolism in the spontaneously hypertensive rat. J Biol Chem 2003; 278: 45209-45215

65 Rangwala SM, Rich AS, Rhoades B, Shapiro JS, Obici S, Rossetti L, Lazar MA. Abnormal glucose homeostasis due to chronic hyperresistinemia. Diabetes 2004; 53: 1937-1941

66 Banerjee RR, Rangwala SM, Shapiro JS, Rich AS, Rhoades B, Qi Y, Wang J, Rajala MW, Pocai A, Scherer PE, Steppan CM, Ahima RS, Obici S, Rossetti L, Lazar MA. Regulation of fasted blood glucose by resistin. Science 2004; 303: 1195-1198

67 Muse ED, Obici S, Bhanot S, Monia BP, MacKay RA, Rajala MW, Scherer PE, Rossetti $L$. Role of resistin in diet-induced hepatic insulin resistance. J Clin Invest 2004; 114: 232-239

$68 \mathrm{Kim} \mathrm{KH}$, Zhao L, Moon Y, Kang C, Sul HS. Dominant inhibitory adipocyte-specific secretory factor (ADSF)/resistin enhances adipogenesis and improves insulin sensitivity. Proc Natl Acad Sci USA 2004; 101: 6780-6785

69 Holcomb IN, Kabakoff RC, Chan B, Baker TW, Gurney A, Henzel W, Nelson C, Lowman HB, Wright BD, Skelton NJ, Frantz GD, Tumas DB, F.V. Peale J, Shelton DL, Hebert CC. FIZZ1, a novel cysteine-rich secreted protein associated with pulmonary inflammation, defines a new gene family. EMBO J 2000; 19: 4046-4055

70 Steppan CM, Brown EJ, Wright CM, Bhat S, Banerjee RR, Dai CY, Enders $G D$, Silberg $D G$, Wen $X, W u G D$, Lazar MA. A family of tissuespecific resistin-like molecules. Proc Natl Acad Sci USA 2001; 98: 502-506

71 Banerjee RR, Lazar MA. Dimerization of resistin and resistin-like molecules is determined by a single cysteine. J Biol Chem 2001; 276: 25970-25973

72 Patel SD, Rajala MW, Rossetti L, Scherer PE, Shapiro L. Disulfidedependent multimeric assembly of resistin family hormones. Science 2004; 304: 1154-1158

73 Steppan CM, Wang J, Whiteman EL, Birnbaum MJ, Lazar MA. Activation of SOCS-3 by resistin. Mol Cell Biol 2005; 25: 1569-1575

74 Kougias P, Chai H, Lin PH, Yao Q Lumsden AB, Chen C. Effects of adipocyte-derived cytokines on endothelial functions: implication of vascular disease. J Surg Res 2005; 126: 121-129

75 Verma S, Li SH, Wang CH, Fedak PW, Li RK, Weisel RD, Mickle DA. Resistin promotes endothelial cell activation: further evidence of adipokine-endothelial interaction. Circulation 2003; 108: 736-740

76 Kawanami D, Maemura K, Takeda N, Harada T, Nojiri T, Imai Y, Manabe I, Utsunomiya K, Nagai R. Direct reciprocal effects of resistin and adiponectin on vascular endothelial cells: a new insight into adipocytokine-endothelial cell interactions. Biochem Biophys Res Commun 2004; 314: 415-419

77 Calabro P, Samudio I, Willerson JT, Yeh ET. Resistin promotes smooth muscle cell proliferation through activation of extracellular signalregulated kinase $1 / 2$ and phosphatidylinositol 3-kinase pathways. Circulation 2004; 110: 3335-3340

78 Axelsson J, Heimburger O, Lindholm B, Stenvinkel P. Adipose tissue and its relation to inflammation: the role of adipokines. J Ren Nutr 2005; 15: 131-136

79 Ohmori R, Momiyama Y, Kato R, Taniguchi H, Ogura M, Ayaori M, Nakamura $H$, Ohsuzu F. Associations between serum resistin levels and insulin resistance, inflammation, and coronary artery disease. J Am Coll Cardiol 2005; 46: 379-380

80 Reilly MP, Lehrke M, Wolfe ML, Rohatgi A, Lazar MA, Rader DJ. Resistin is an inflammatory marker of atherosclerosis in humans. Circulation 2005; 111: 932-939
81 Burnett MS, Lee CW, Kinnaird TD, Stabile E, Durrani S, Dullum MK, Devaney JM, Fishman C, Stamou S, Canos D, Zbinden S, Clavijo LC, Jang GJ, Andrews JA, Zhu J, Epstein SE. The potential role of resistin in atherogenesis. Atherosclerosis 2005; 182: 241-248

82 Winder WW, Hardie DG. AMP-activated protein kinase, a metabolic master switch: possible roles in type 2 diabetes. Am J Physiol 1999; 277: E1-E10

83 Senn JJ, Klover PJ, Nowak IA, Zimmers TA, Koniaris LG, Furlanetto RW, Mooney RA. Suppressor of cytokine signaling-3 (SOCS-3), a potential mediator of interleukin-6-dependent insulin resistance in hepatocytes. J Biol Chem 2003; 278: 13740-13746

84 Rui L, Yuan M, Frantz D, Shoelson S, White MF. SOCS-1 and SOCS-3 block insulin signaling by ubiquitin-mediated degradation of IRS1 and IRS2. J Biol Chem 2002; 277: 42394-42398

85 Emanuelli B, Peraldi P, Filloux C, Chavey C, Freidinger K, Hilton DJ, Hotamisligil GS, Obberghen E Van. SOCS-3 inhibits insulin signaling and is up-regulated in response to tumor necrosis factor-alpha in the adipose tissue of obese mice. J Biol Chem 2001; 276: 4794447949

86 Ueki K, Kondo T, Tseng YH, Kahn CR. Central role of suppressors of cytokine signaling proteins in hepatic steatosis, insulin resistance, and the metabolic syndrome in the mouse. Proc Natl Acad Sci USA 2004; 101: 10422-10427

87 Graveleau C, Zaha VG, Mohajer A, Banerjee RR, Dudley-Rucker N Steppan CM, Rajala MW, Scherer PE, Ahima RS, Lazar MA, Abel ED. Mouse and human resistin impair glucose transport in primary mouse cardiomyocytes and oligomerization is required for this biological action. J Biol Chem 2005; 280: 31679-31685

88 Yamauchi T, Kamon J, Ito Y, Tsuchida A, Yokomizo T, Kita S, Sugiyama T, Miyagishi M, Hara K, Tsunoda M, Murakami K, Ohteki T, Uchida S, Takekawa S, Waki H, Tsuno NH, Shibata Y, Terauchi Y, Froguel P, Tobe K Koyasu S, Taira K, Kitamura T, Shimizu T, Nagai R, Kadowaki T. Cloning of adiponectin receptors that mediate antidiabetic metabolic effects. Nature 2003; 423: 762-769

89 Yang RZ, Huang Q Xu A, MacLenithan JC, Eisen JA, Shuldiner AR, Alkan S, Gong DW. Comparative studies of resistin expression and phylogenomics in human and mouse. Biochem Biophys Res Commun 2003; 310: 927-935

90 Seo JB, Noh MJ, Yoo EJ, Park SY, Park J, Lee IK, Park SD, Kim JB. Functional characterization of the human resistin promoter with adipocyte determination- and differentiation-dependent factor 1 /sterol regulatory element binding protein 1c and CCAAT enhancer binding protein-alpha. Mol Endocrinol 2003; 17: 1522-1533

91 Silswal N, Singh AK, Aruna B, Mukhopadhyay S, Ghosh S, Ehtesham NZ. Human resistin stimulates the pro-inflammatory cytokines TNFalpha and IL-12 in macrophages by NF-kappaB-dependent pathway. Biochem Biophys Res Commun 2005; 334: 1092-1101

92 MacTernan CL, MacTernan PG, Harte AL, Levick PL, Barnett AH, Kumar S. Resistin, central obesity, and type 2 diabetes. Lancet 2002; 359: 46-47

93 Savage DB, Sewter CP, Klenk ES, Segal DG, Vidal-Puig A, Considine RV, $O$ 'Rahilly $S$. Resistin/Fizz3 expression in relation to obesity and peroxisome proliferator-activated receptor-gamma action in humans. Diabetes 2001; 50: 2199-2202

94 Bokarewa M, Nagaev I, Dahlberg L, Smith U, Tarkowski A. Resistin, an adipokine with potent proinflammatory properties. J Immunol 2005; 174: 5789-5795

95 Gerber M, Boettner A, Seidel B, Lammert A, Bar J, Schuster E, Thiery J, Kiess W, Kratzsch J. Serum resistin levels of obese and lean children and adolescents: biochemical analysis and clinical relevance. J Clin Endocrinol Metab 2005; 90: 4503-4509

96 Chen CC, Li TC, Li CI, Liu CS, Wang HJ, Lin CC. Serum resistin level among healthy subjects: Relationship to anthropometric and metabolic parameters. Metabolism 2005; 54: 471-475

97 Pfutzner A, Langenfeld $M$, Kunt $T$, Lobig $M$, Forst $T$. Evaluation of human resistin assays with serum from patients with type 2 diabetes and different degrees of insulin resistance. Clin Lab 2003; 49: $571-576$

98 Lee JH, Chan JL, Yiannakouris N, Kontogianni M, Estrada E, Seip R, Orlova $C$, Mantzoros CS. Circulating resistin levels are not associated with obesity or insulin resistance in humans and are not regulated by fasting or leptin administration: cross-sectional and interventional studies in normal, insulin-resistant, and diabetic subjects. J Clin Endocrinol Metab 2003; 88: 4848-4856

99 Kielstein JT, Becker B, Graf S, Brabant G, Haller H, Fliser D. Increased resistin blood levels are not associated with insulin resistance in patients with renal disease. Am J Kidney Dis 2003; 42: 62-66 
100 Bo S, Gambino R, Pagani A, Guidi S, Gentile L, Cassader M, Pagano GF. Relationships between human serum resistin, inflammatory markers and insulin resistance. Int J Obes Relat Metab Disord 2005; 29 : $1315-1320$

101 Hasegawa G, Ohta M, Ichida Y, Obayashi H, Shigeta M, Yamasaki M, Fukui M, Yoshikawa T, Nakamura $N$. Increased serum resistin levels in patients with type 2 diabetes are not linked with markers of insulin resistance and adiposity. Acta Diabetol 2005; 42: 104-109

102 Pagano C, Marin O, Calcagno A, Schiappelli P, Pilon C, Milan G, Bertelli M, Fanin E, Andrighetto $G$, Federspil $G$, Vettor $R$. Increased serum resistin in adults with prader-willi syndrome is related to obesity and not to insulin resistance. J Clin Endocrinol Metab 2005; 90: 4335-4340

103 Kunnari A, Ukkola O, Kesaniemi YA. Resistin polymorphisms are associated with cerebrovascular disease in Finnish Type 2 diabetic patients. Diabet Med 2005; 22: 583-589

104 Harsch IA, Koebnick C, Wallaschofski H, Schahin SP, Hahn EG, Ficker JH, Lohmann T, Konturek PC. Resistin levels in patients with obstructive sleep apnoea syndrome-the link to subclinical inflammation? Med Sci Monit 2004; 10: CR510-515

105 Azuma K, Oguchi S, Matsubara Y, Mamizuka T, Murata M, Kikuchi H, Watanabe K, Katsukawa F, Yamazaki H, Shimada A, Saruta T. Novel resistin promoter polymorphisms: association with serum resistin level in Japanese obese individuals. Horm Metab Res 2004; 36: 564-570

106 Vendrell J, Broch M, Vilarrasa N, Molina A, Gomez JM, Gutierrez C, Simon I, Soler J, Ri . Resistin, adiponectin, ghrelin, leptin, and proinflammatory cytokines: relationships in obesity. Obes Res 2004; 12 : 962-971

107 Vozarova de Courten B, Degawa-Yamauchi M, Considine RV, Tataranni PA. High serum resistin is associated with an increase in adiposity but not a worsening of insulin resistance in Pima Indians. Diabetes 2004; 53: $1279-1284$

108 Silha JV, Murphy LJ. Serum resistin (FIZZ3) protein is increased in obese humans. J Clin Endocrinol Metab 2004; 89: 1977 ; authors' reply $1977-1978$

109 Heilbronn LK, Rood J, Janderova L, Albu JB, Kelley DE, Ravussin E, Smith SR. Relationship between serum resistin concentrations and insulin resistance in nonobese, obese, and obese diabetic subjects. J Clin Endocrinol Metab 2004; 89: 1844-1848

110 Valsamakis G, MacTernan PG, Chetty R, Al Daghri N, Field A, Hanif W, Barnett AH, Kumar S. Modest weight loss and reduction in waist circumference after medical treatment are associated with favorable changes in serum adipocytokines. Metabolism 2004; 53: 430-434

111 Youn BS, Yu KY, Park HJ, Lee NS, Min SS, Youn MY, Cho YM, Park YJ, Kim SY, Lee HK, Park KS. Plasma resistin concentrations measured by enzyme-linked immunosorbent assay using a newly developed monoclonal antibody are elevated in individuals with type 2 diabetes mellitus. J Clin Endocrinol Metab 2004; 89: 150-156

112 Fujinami A, Obayashi $H$, Ohta K, Ichimura T, Nishimura M, Matsui $H$, Kawahara Y, Yamazaki M, Ogata M, Hasegawa G, Nakamura N, Yoshikawa T, Nakano K, Ohta M. Enzyme-linked immunosorbent assay for circulating human resistin: resistin concentrations in normal subjects and patients with type 2 diabetes. Clin Chim Acta 2004; 339: 57-63

113 MacTernan PG, Fisher FM, Valsamakis G, Chetty R, Harte A, MacTernan CL, Clark PM, Smith SA, Barnett AH, Kumar S. Resistin and type 2 diabetes: regulation of resistin expression by insulin and rosiglitazone and the effects of recombinant resistin on lipid and glucose metabolism in human differentiated adipocytes. J Clin Endocrinol Metab 2003; 88: 6098-6106
114 Degawa-Yamauchi M, Bovenkerk JE, Juliar BE, Watson W, Kerr K, Jones $R$, Zhu Q Considine RV. Serum resistin (FIZZ3) protein is increased in obese humans. J Clin Endocrinol Metab 2003; 88: 5452-5455

115 Azuma K, Katsukawa F, Oguchi S, Murata M, Yamazaki H, Shimada A, Saruta $T$. Correlation between serum resistin level and adiposity in obese individuals. Obes Res 2003; 11: 997-1001

116 Pajvani UB, Hawkins M, Combs TP, Rajala MW, Doebber T, Berger JP, Wagner JA, Wu M, Knopps A, Xiang AH, Utzschneider KM, Kahn SE, Olefsky JM, Buchanan TA, Scherer PE. Complex distribution, not absolute amount of adiponectin, correlates with thiazolidinedione-mediated improvement in insulin sensitivity. J Biol Chem 2004; 279: 12152-12162

117 Diez JJ, Iglesias $P$, Fernandez-Reyes MJ, Aguilera A, Bajo MA, Alvarez-Fidalgo $P$, Codoceo $R$, Selgas $R$. Serum concentrations of leptin, adiponectin and resistin, and their relationship with cardiovascular disease in patients with end-stage renal disease. Clin Endocrinol (Oxf) 2005; 62: 242-249

118 Al-Daghri ND, Chetty RD, MacTernan Pg PD, Al-Rubeaan KD, OP OA-A, Jones $A D$, Kumar SP. Serum resistin is associated with $C$ - reactive protein \& LDL cholesterol in type 2 diabetes and coronary artery disease in a Saudi population. Cardiovasc Diabetol 2005; 4: 10

119 Shetty GK, Economides PA, Horton ES, Mantzoros CS, Veves A. Circulating adiponectin and resistin levels in relation to metabolic factors, inflammatory markers, and vascular reactivity in diabetic patients and subjects at risk for diabetes. Diabetes Care 2004; 27 : 2450-2457

120 Kaser S, Kaser A, Sandhofer A, Ebenbichler CF, Tilg H, Patsch JR. Resistin messenger-RNA expression is increased by proinflammatory cytokines in vitro. Biochem Biophys Res Commun 2003; 309: 286-290

121 Xita N, Georgiou I, Tsatsoulis A, Kourtis A, Kukuvitis A, Panidis D. A polymorphism in the resistin gene promoter is associated with body mass index in women with polycystic ovary syndrome. Fertil Steril 2004; 82: 1466-1467

122 Conneely KN, Silander K, Scott LJ, Mohlke KL, Lazaridis KN, Valle TT, Tuomilehto J, Bergman RN, Watanabe RM, Buchanan TA, Collins FS, Boehnke M. Variation in the resistin gene is associated with obesity and insulin-related phenotypes in Finnish subjects. Diabetologia 2004; 47: 1782-1788

123 Mattevi VS, Zembrzuski VM, Hutz MH. A resistin gene polymorphism is associated with body mass index in women. Hum Genet 2004; 115: 208-212

124 Smith SR, Bai F, Charbonneau C, Janderova L, Argyropoulos G. A promoter genotype and oxidative stress potentially link resistin to human insulin resistance. Diabetes 2003; 52: 1611-1618

125 Wang $H$, Chu WS, Hemphill C, Elbein SC. Human resistin gene: molecular scanning and evaluation of association with insulin sensitivity and type 2 diabetes in Caucasians. J Clin Endocrinol Metab 2002; 87: 2520-2524

126 Engert JC, Vohl MC, Williams SM, Lepage P, Loredo-Osti JC, Faith J, Dore C, Renaud Y, Burtt NP, Villeneuve A, Hirschhorn JN, Altshuler D, Groop LC, Despres JP, Gaudet D, Hudson TJ. 5' flanking variants of resistin are associated with obesity. Diabetes 2002; 51: 1629-1634

127 Chung SS, Choi HH, Kim KW, Cho YM, Lee HK, Park KS. Regulation of human resistin gene expression in cell systems: an important role of stimulatory protein 1 interaction with a common promoter polymorphic site. Diabetologia 2005; 48: 1150-1158

128 Cho YM, Youn BS, Chung SS, Kim KW, Lee HK, Yu KY, Park HJ, Shin HD, Park KS. Common genetic polymorphisms in the promoter of resistin gene are major determinants of plasma resistin concentrations in humans. Diabetologia 2004; 47: 559-565 